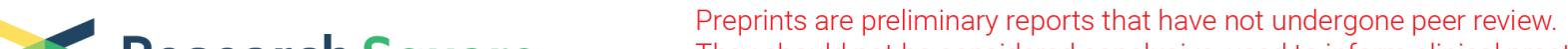 Research Square They should not be considered conclusive, used to inform clinical practice, or referenced by the media as validated information.
}

\section{Molecular detection of tick-borne pathogens in cattle from Saudi Arabia}

\author{
Abdullah D Alanazi ( $\nabla$ aalanazi@su.edu.sa ) \\ Shaqra University https://orcid.org/0000-0002-4862-7668 \\ Abdulaziz S Alouffi \\ King Abdullah University of Science and Technology \\ Mohammad Yahya Alshahrani \\ King Khalid University College of Medicine \\ Mohamed S Alyousif \\ King Saud University College of Science \\ Hend H.A.M. Abdullah \\ Veterinary Research Division \\ Ahmad M Allam \\ Veterinary Research Divison \\ Bassma S.M. Elsawy \\ Veterinary Research Division \\ Sobhy Abdel-Shafy \\ Veterinary Research Division \\ Muslimah Alsulami \\ University of Jeddah
}

\section{Research}

Keywords: Tick-borne pathogens, Cattle, Saudi Arabia, Theileria annulata, Theileria ovis

Posted Date: May 13th, 2020

DOI: https://doi.org/10.21203/rs.3.rs-27577/v1

License: (c) (1) This work is licensed under a Creative Commons Attribution 4.0 International License.

Read Full License 


\section{Abstract \\ Background and aim:}

Babesiosis and anaplasmosis are tick-borne diseases that affect the health of cattle and may be also responsible for remarkable economic losses. This study aimed to detect the presence of the causative agents of babesiosis and anaplasmosis among cattle in different provinces in Saudi Arabia and to characterise their species genetically.

\section{Methodology:}

A total of 362 blood samples were taken from cattle in four regions (Riyadh, Al-Kharj, Al-Hasa and AlQassim) of Saudi Arabia and were molecularly screened by polymerase chain reaction (PCR) of partial 18S rRNA and 23S rRNA genes to detect Babesia and Anaplasma species.

\section{Results}

The overall prevalence of both Babesia and Anaplasma in cattle was $2.49 \%$ and $5.80 \%$, respectively. Theileria annulata (T. annulata) and Theileria ovis (T. ovis) were found in seven (1.93\%) and two (0.55\%) of the 362 samples, respectively. Anaplasma ovis (A. ovis) was detected in 21 (5.80\%) of 362 samples. Likewise, four of the cattle were found to be co-infected with more than one pathogen (1.10\%). All cattle samples tested negative for other species of Babesia, Theileria and Anaplasma.

\section{Conclusion}

The presence of T. ovis and A. ovis has been herein reported in Saudi Arabia. The presence of two novel genotypes of $T$. annulata is also reported in Saudi Arabian cattle. Further molecular surveys on larger numbers of samples from the entire country are needed in order to address correctly the prevalence and geographical distribution of the tick-borne disease.

\section{Introduction}

Tick-borne diseases (TBDs) including piroplasmosis and anaplasmosis are mainly distributed in tropical and temperate regions [1,2]. The main causative agents of bovine piroplasmosis belong to the genera Babesia (Piroplasmida; Babesiidae) and Theileria (Piroplasmida; Theileriidae). Furthermore, pathogens within the genus Anaplasma (Rickettsiales; Anaplasmataceae) cause bovine anaplasmosis [3]. TBDs affect the health of livestock and are responsible for heavy economic losses. They also pose a potential risk regarding transmission of disease to humans [4].Cattle production is severely affected by various diseases, especially in the absence of adequate veterinary services [5] and many endo- and ectoparasites affect the health, productivity and performance of the animals, including ticks $[6,7]$. 
The cattle population in Saudi Arabia numbered approximately 350,000 in 2015. The highest percentages were in the Eastern and Central regions (Saudi Arabia General Authority for StatisticsGen, 2015 at https://www.stats.gov.sa/en). These regions contain the most cattle imported to Saudi Arabia from Europe [8]. In Saudi Arabia, cattle are infested by several species of hard ticks (Acari, Ixodidae), mainly Hyalomma anatolicum anatolicum, (H. anatolicum anatolicum), Amblyomma variegatum, Rhipicephalus praetextatus and Hyalomma marginatum rufipes $[9,10,11]$. These ticks can act as vectors for a variety of pathogens of veterinary importance, and several tick-borne diseases are known to be endemic in Saudi Arabia. However, knowledge of tick-borne pathogens (TBPs) in cattle of this country is very limited. A few molecular epidemiological studies have been conducted on a limited number of animals $[12,13,14]$. Therefore, the present study aimed to determine the prevalence of ixodid ticks and investigate their associated pathogens at a molecular level among cattle in Saudi Arabia.

\section{Materials And Methods}

\section{Ethical approval}

This study was revised and approved by the Ethical Research Committee, Deanship of Scientific Research, King Khalid University, according to the ethical principles of human and animal research (Approval no. (ECM\#2019-74) - (HAPO-06-B-001).

\section{Sampling procedures}

The cross-sectional study was conducted from May to October 2018 in four regions of Saudi Arabia: Riyadh $\left(24^{\circ} 0^{\prime} \mathrm{N}, 45^{\circ} 30^{\prime} \mathrm{E}\right)$; Al-Kharj $\left(24^{\circ} 08^{\prime} \mathrm{N}, 47^{\circ} 18 \mathrm{E}\right)$; Al-Hasa $\left(25^{\circ} 23^{\prime} \mathrm{N}, 49^{\circ} 36 \mathrm{E}\right)$ and Al-Qassim $\left(25^{\circ} 48^{\prime} \mathrm{N}\right.$, $42^{\circ} 52 \mathrm{E}$ ) (Figure 1). All cows were apparently healthy at the time of sampling and was screened for tick infestation. Ticks found within 15 min were collected (2-5 ticks/infested animal) and placed in labelled tubes containing $70 \%$ ethanol that were individualised per cow. Ticks were identified to the species level by examination of morphological features and use of morphological keys $[15,16,17]$. Each cow was categorised according to age and gender.

Blood samples were collected from each animal $(2-5 \mathrm{ml})$ from the jugular vein into vacutainer tubes with ethylenediaminetetraacetic acid (EDTA) (BD Vacutainer ${ }^{\circledR}$ Tube, Gribbles Pathology, VIC, Australia) and transported in ice boxes to the molecular laboratory, Department of Biological Sciences, Faculty of Science and Humanities, Shaqra University, for DNA extraction.

\section{Molecular procedures}

Total genomic DNA (gDNA) was isolated from the blood samples using the Wizard ${ }^{\circledR}$ Genomic DNA Purification Kit (Promega, Madison, WI, USA) following manufacturer's instruction. Aliquots of between $50 \mu \mathrm{l}$ and $100 \mu \mathrm{l}$ of gDNA from each sample were stored at $-20^{\circ} \mathrm{C}$ prior to molecular analysis. 
The primers were designed to target a conserved region that encoded for ribosomal 18S rRNA (969 bp) and 238S rRNA(485 bp) to detect the DNA of Babesia [18] and Anaplasma [19] respectively (Table 1). Polymerase chain reaction (PCR) assays were performed in an automated BIO-RAD Thermal Cycler (BIORAD, Singapore) using one PCR master mix (GeneDireX, Taiwan). The PCR conditions for the Babesia amplification were: one incubation step at $95^{\circ} \mathrm{C}$ for $15 \mathrm{~min} ; 35$ cycles of $1 \mathrm{~min}$ at $95^{\circ} \mathrm{C} ; 30 \mathrm{~s}$ of annealing at $58^{\circ} \mathrm{C}$ and $1 \mathrm{~min}$ at $72{ }^{\circ} \mathrm{C}$; followed by a final extension for $5 \mathrm{~min}$ at $72{ }^{\circ} \mathrm{C}$. Positive and negative controls were included. PCR conditions of Anaplasma amplification were: an initial denaturation step at $95^{\circ} \mathrm{C}$ for $15 \mathrm{~min}$; then 40 cycles that consisted of $1 \mathrm{~min}$ denaturation at $95^{\circ} \mathrm{C}, 1 \mathrm{~min}$ annealing at $55^{\circ} \mathrm{C}$, a 1 min extension at $72{ }^{\circ} \mathrm{C}$, a final extension cycle at $72{ }^{\circ} \mathrm{C}$ for $7 \mathrm{~min}$ and cooling of the reactions at $15^{\circ} \mathrm{C}$. Distilled water samples were used as negative controls. Positive genomic controls of Theileria annulata (T. annulata) and Anaplasma marginale were included. The amplifications were confirmed by electrophoresis on a $1.5 \%$ agarose gel, stained with Red Safe and examined by ultraviolet transillumination. A DNA molecular weight marker (100bp DNA Ladder H3 RTU, GeneDireX, Taiwan) was used to estimate the size of the products. The PCR products of the positive samples were purified by use of a PCR Clean-Up \& Gel Extraction Kit (GeneDireX, Taiwan) according to the manufacturer's instructions.

\section{Sequencing and phylogenetic analyses}

The purified PCR products were sequenced at Macrogene Lab Technology, Korea. The obtained sequences were assembled using ChromasPro software (ChromasPro 1.7, Technelysium Pty Ltd., Tewantin, Australia). The obtained sequences of Babesia and Anaplasma were submitted to GenBank and then compared with those available in the GenBank database by the US National Centre for Biotechnology Information Basic Local Alignment Search Tool (NCBI BLAST) (http://blast.ncbi.nlm.nih.gov/Blast.cgi). Morover, the sequences obtained from positive samples and to sequences of validated species already available in GenBank were aligned using Bioedit software version 7.0.5.3 (Clustal W multiple alignment) [20]. For taxonomic analyses, the maximum-likelihood phylogenetic trees were constructed using Molecular Evolutionary Genetics Analysis (MEGA) software version X [21] with 500 bootstrap replications.

\section{Statistical analysis}

The significant differences regarding the prevalence of infections with Babesia and Anaplasma and their risk factors, such as gender and age of the cattle and their levels of tick infestation, were calculated by $x^{2}$ test using a Statistical Package for the Social Sciences (SPSS) program, version 20.0, at $P<0.05$.

\section{Results}

Of the 362 cattle examined, nine (2.49\%) were found to be infected with Babesia, 21 (5.80\%) with Anaplasma and four (1.10\%) were found co-infected with more than one pathogen (Table 2). Anaplasma ovis (A. ovis) was the most prevalent pathogen (5.80\%) followed by T. annulata (1.93\%) and T. ovis $(0.55 \%)$ (Table 2$)$. All the samples tested negative for other species of Babesia, Theileria and Anaplasma. 
Among the four provinces, the highest prevalence of infection observed in Riyadh (12.14\%) and the lowest recorded in Al-Qassim (3.03\%). In the region of Al-Kharj, there was no infection by TBDs (Table 2).

Of the 362 examined cattle, $245(67.7 \%)$ were infested by ticks $(n=541)$. of which, $328(60.6 \%)$ were males and 213 (39.4\%) were females. The most representative tick species were $H$. anatolicum anatolicum (207, 38.3\%), H. dromedarii (116, 21.4\%), H. impeltatum (97, 18\%), Rhipicephalus (Boophilus) annulatus (71, 13.1\%), Rhipicephalus turanicus $(47,8.7 \%$ ) and $H$. excavatum (three, $0.5 \%)$. Data regarding sex and age of the sampled cattle along with the number and percentage positivity for TBPs are reported in Table 3.

The PCR products showed the expected band size for each pathogen (Figures 2 and 3 ). By BLAST analysis, T. annulata and T. ovis were identified. Two novel genotypes of $T$. annulata were identified in this study (GenBank: MN826137 and MN826138) that were $99.8 \%$ identical to T. annulata in $H$. anatolicum anatolicum from Hofuf, Saudi Arabia (GenBank: MK300062) and 99.2\% identical to $T$. annulata in cattle from Egypt (GenBank: MN625888 and MN625889). Moreover, a new genotype of $T$. ovis (GenBank: MN826139) was detected in cattle with 98\% similarity to those of sheep from Egypt (GenBank: MN625886). In addition, in the present study, a novel $A$. ovis genotype was detected in cattle (GenBank: MN880224) with $99 \%$ similarity to those of $A$. ovis detected in cattle from Egypt (GenBank: MN625933). The phylogenetic tree of these genotypes are illustrated in Figures $\mathbf{4}$ and $\mathbf{5}$.

\section{Discussion}

The high prevalence of tick infestation (67.7\%) and of TBPs (8.3\%) among cattle in Saudi Arabia represents a potential threat to the health and welfare of these animals as well as to livestock production. The most prevalent tick species was Hyalomma anatolicum anatolicum, which is considered to be the main species that parasitises cattle [10, 22, 23]. Camels are the main host for the species Hyalomma dromedarii, although it can also infest cattle, sheep, goats, horses and donkeys [24]. The species Hyalomma impeltatum infests a wide range of mammalian hosts including cattle [25]. These tick species are the main vectors of Babesia spp., Theileria spp. and Anaplasma spp. of domestic and wild ungulates in Saudi Arabia [12, 13, 26, 27, 28, 29, 30]. Rhipicephalus (Boophilus) annulatus has been reported from cattle in Jazan in the south-west and from animals in central parts of Saudi Arabia [31, 32]. This tick species is an efficient vector of Babesia bovis globally [33]. The other two species herein identified in cattle, Rhipicephalus turanicus and Hyalomma excavatum, usually infest sheep, goats and horses [10, 11, 31] begin found herein on cattle might be due to husbandry practices in desert areas, where livestock share the same environment.

The overall TBP infection prevlance in cattle reported in this study was $8.3 \%$ which is in agreement with previous findings $[13,26]$. Also findings of this study indicate that $T$. annulata is present in the central and eastern parts of Saudi Arabia, which overlap with the distribution of $H$. anatolicum anatolicum, the putative vector of $T$. annulata $[8,31]$. 
T. ovis is a non-pathogenic parasite that is widespread in Saudi Arabia, particularly in sheep and goats [34]. Moreover, according to experimental transmission studies [35], $\mathrm{H}$. anatolicum anatolicum could be the vector of this parasite in Saudi Arabia. This tick has been found to infest sheep and goats in Saudi Arabia $[10,31]$.

This study reports two novel T. annulata genotypes (GenBank: MN826137 and MN826138) that are 99.8\% identical to T. annulata in H. anatolicum anatolicum from the Hofuf region of Saudi Arabia (GenBank: MK300062) and 99.2\% to T. annulata in cattle from Egypt (GenBank: MN625888 and MN625889). The results are in agreement with already published data of occurrence of $T$. annulata in cattle in Saudi Arabia $[8,13,14]$. Moreover, a new genotype of T. ovis (GenBank: MN826139) has been detected in cattle blood with $98 \%$ similarity to those of T. ovis detected in sheep from Egypt (GenBank: MN625886). A novel A. ovis genotype has been identified in Saudi cattle (GenBank: MN880224) with 99\% similarity to those of $A$. ovis detected in cattle from Egypt (GenBank: MN625933). However, this study do not cover all Saudi Arabian regions and dose give a clear picture of TBPs distrbutions and prevalence in Saudi cattle, therefore further epidomolgical and molecular studies are required in order to elaborate better strategic control plans and assess the risk to cattle health and productivity.

\section{Conclusion}

This is the first study that reported T. ovis and A. ovis in cattle from Saudi Arabia, Futhermore, two new genotypes of $T$. annulata in cattle were recorded and therefore, cattle may be considered as carriers for Babesia and Anaplasma spp. of other ruminants in Saudi Arabia. Further extensive molecular surveys on a large numbers of of animals from the whole country are needed in order to address correctly the prevalence and geographical distribution of TBPs.. This in turn will help in the design and implementation of effective preventive and control measures.

\section{Declarations}

\section{Acknowledgements}

This study was kindly supported by King Khalid University under grant number (G.R.P2/78-40.). The authors also would like. The authors would like to thank the staff of the Biological Science Department, Faculty of Science and Humanities, Shaqra University, and the staff of the Department of Parasitology and Animal Diseases, Veterinary Research Division, National Research Centre, Dokki, Giza, Egypt. The authors would like to thank Dr/ Jairo Alfonso Mendoza-Roldan and Prof/ Domenico Otranto for valuable comments.

\section{Declarations}

Ethics approval and consent to participate 
The performance of blood sampling for this study was approved by the Ethical Research Committee, Deanship of Scientific Research, King Khalid University, according to the ethical principles of human and animal research (Approval no. (ECM\#2019-74) (HAPO-06-B-001).

\section{Consent for publication}

Not applicable.

\section{Competing interests}

The authors declare that they have no competing interests.

\section{Funding}

This project was supported by the Deanship of Scientific Research, King Khalid University, under grant number G.R.P2/78-40.

\section{Authors' contributions}

All authors shared in the design of the plan of this study. ADA, MSA, ASA, MYA collected blood samples from cattle and extracted DNA from the blood samples. ADA, HHAMA, AMA, BSME and SA participated in the conduction of PCR protocols, purification of PCR products, sequence analyses, construction of the phylogenetic tree and analyses of the data. ADA, SA, HHAMA and AMA co-wrote the manuscript. $A D A, M S A$ and $S A$ reviewed and wrote the final draft of the manuscript. All authors revised and approved the final version of the manuscript.

\section{References}

1. Vannier E, Krause PJ. Babesiosis. Hunter's Tropical Medicine and Emerging Infectious Diseases: Elsevier; 2020. p. 799-802.

2. Jabbar A, Abbas T, Saddiqi HA, Qamar MF, Gasser RB. Tick-borne diseases of bovines in Pakistan: major scope for future research and improved control. Parasites \& vectors. 2015;8 1:283.

3. de Castro JJ. Sustainable tick and tickborne disease control in livestock improvement in developing countries. Veterinary parasitology. 1997;71 2-3:77-97.

4. Dantas-Torres F, Chomel BB, Otranto D. Ticks and tick-borne diseases: a One Health perspective. Trends in parasitology. 2012;28 10:437-46.

5. Hailemariam Z, Krücken J, Baumann M, Ahmed JS, Clausen P-H, Nijhof AM. Molecular detection of tick-borne pathogens in cattle from Southwestern Ethiopia. PLoS One. 2017;12 11.

6. Beugnet F, Marié J-L. Emerging arthropod-borne diseases of companion animals in Europe. Veterinary parasitology. 2009;163 4:298-305.

7. Diuk-Wasser MA, Vannier E, Krause PJ. Coinfection by Ixodes tick-borne pathogens: ecological, epidemiological, and clinical consequences. Trends in parasitology. 2016;32 1:30-42. 
8. Omer O, El-Malik K, Mahmoud O, Haroun E, Hawas A, Sweeney D, et al. Haematological profiles in pure bred cattle naturally infected with Theileria annulata in Saudi Arabia. Veterinary parasitology. 2002;107 1-2:161-8.

9. Al-Khalifa MS, Al-Asgah NA, Diab FM. Ticks (Acari: Ixodidae) infesting common domestic animals in Al-Qasim Province, Saudi Arabia. Journal of medical entomology. 1984;21 1:114-5.

10. Diab F, Al-Khalifa M, Al-Asgah N, Hussein H, Khalil G. Ticks (Acari: Argasidae, Ixodidae) infesting livestock in Saudi Arabia. Fauna of Arabia. 2006;22:233.

11. Alanazi AD, Al-Mohammed HI, Alyousif MS, Said AE, Salim B, Abdel-Shafy S, et al. Species Diversity and Seasonal Distribution of Hard Ticks (Acari: Ixodidae) Infesting Mammalian Hosts in Various Districts of Riyadh Province, Saudi Arabia. Journal of medical entomology. 2019;56 4:1027-32.

12. El-Metenawy T. Prevalence of blood parasites among cattle at the central area of Saudi Arabia. Veterinary parasitology. 2000;87 2-3:231-6.

13. Al-Khalifa M, Hussein H, Diab F, Khalil G. Blood parasites of livestock in certain regions in Saudi Arabia. Saudi journal of biological sciences. 2009;16 2:63-7.

14. Ghafar MW, Amer SA. A preliminary molecular survey of Babesia divergens and first evidence of Theileria annulata in cattle from Saudi Arabia. Veterinary World. 2019;12 2:266.

15. Hoogstraal H, Wassef H, Büttiker W. Ticks (Acarina) of Saudi Arabia. Fam. Argasidae, Ixodidae. Fauna of Saudi Arabia. 1981;3:25-110.

16. Estrada-Peña A, Bouattour A, Camicas J, Walker A. A guide to identification of species. Bioscience Reports, London, United Kingdom. 2004.

17. Walker JB, Keirans JE, Horak IG. The genus Rhipicephalus (Acari, Ixodidae): a guide to the brown ticks of the world. Cambridge University Press; 2005.

18. Dahmana H, Amanzougaghene N, Davoust B, Normand T, Carette O, Demoncheaux J-P, et al. Great diversity of Piroplasmida in Equidae in Africa and Europe, including potential new species. Veterinary Parasitology: Regional Studies and Reports. 2019;18:100332.

19. Dahmani M, Davoust B, Tahir D, Raoult D, Fenollar F, Mediannikov O. Molecular investigation and phylogeny of Anaplasmataceae species infecting domestic animals and ticks in Corsica, France. Parasites \& vectors. 2017;10 1:302.

20. Hall TA: BioEdit: a user-friendly biological sequence alignment editor and analysis program for Windows 95/98/NT. In: Nucleic acids symposium series1999: [London]: Information Retrieval Ltd., c1979-c2000.: 95-8.

21. Kumar S, Stecher G, Li M, Knyaz C, Tamura K. MEGA X: molecular evolutionary genetics analysis across computing platforms. Molecular biology and evolution. 2018;35 6:1547-9.

22. Singh NK, Rath SS. Epidemiology of ixodid ticks in cattle population of various agro-climatic zones of Punjab, India. Asian Pacific journal of tropical medicine. 2013;6 12:947-51.

23. Biglari $P$, Bakhshi $H$, Chinikar S, Belqeiszadeh $H$, Ghaffari $M$, Javaherizadeh $S$, et al. Hyalomma anatolicum as the main infesting tick in an important livestock rearing region, central area of Iran. 
Iranian journal of public health. 2018;47 5:742.

24. Apanaskevich DA, Schuster AL, Horak IG. The genus Hyalomma: VII. Redescription of all parasitic stages of H.(Euhyalomma) dromedarii and H.(E.) schulzei (Acari: Ixodidae). Journal of medical entomology. 2008;45 5:817-31.

25. Guglielmone AA, Robbins RG, Apanaskevich DA, Petney TN, Estrada-Peña A, Horak IG. The hard ticks of the world. New York: Springuer. 2014.

26. El-Azazy O, El-Metenawy T, Wassef H. Hyalomma impeltatum (Acari: Ixodidae) as a potential vector of malignant theileriosis in sheep in Saudi Arabia. Veterinary Parasitology. 2001;99 4:305-9.

27. Alanazi AD, Said AE, Morin-Adeline V, Alyousif MS, Šlapeta J. Quantitative PCR detection of Theileria equi using laboratory workflows to detect asymptomatic persistently infected horses. Veterinary parasitology. 2014;206 3-4:138-45.

28. ALanazi AD, Abdullah S, Helps $C$, Wall R, Puschendorf R, ALHarbi SA, et al. Tick-borne pathogens in ticks and blood samples collected from camels in Riyadh province, Saudi Arabia. 2018.

29. Salim B, Alanazi AD, Omori R, Alyousif MS, Alanazi IO, Katakura K, et al. Potential role of dogs as sentinels and reservoirs for piroplasms infecting equine and cattle in Riyadh City, Saudi Arabia. Acta tropica. 2019;193:78-83.

30. Alanazi AD, Nguyen VL, Alyousif MS, Manoj RR, Alouffı AS, Donato R, et al. Ticks and associated pathogens in camels (Camelus dromedarius) from Riyadh Province, Saudi Arabia. Parasites \& Vectors. 2020;13 1:1-9.

31. Al-Khalifa M, Hussein H, Al-Asgah N, Diab F. Ticks (Acari: Ixodidae) infesting local domestic animals in western and southern Saudi Arabia. Arab Gulf J Sci Res B. 1987;5:301-19.

32. Al-Shammery KA, Fetoh B, Alshammari AM. Differentiation between common tick species using molecular biology techniques in Saudi Arabia. J World Academy of Sci, Eng And Tech. 2011;73:3057.

33. Kamani J, Apanaskevich D, Gutiérrez R, Nachum-Biala Y, Baneth G, Harrus S. Morphological and molecular identification of Rhipicephalus (Boophilus) microplus in Nigeria, West Africa: a threat to livestock health. Experimental and Applied Acarology. 2017;73 2:283-96.

34. Alanazi AD, Said AE, Ghoneim AM, Alyousif MS, Alanazi IO. A comprehensive evaluation and first molecular report of Theileria ovis infection in small ruminants in Saudi Arabia. Tropical animal health and production. 2019;51 1:89-98.

35. Hooshmand-Rad P, Hawa N. Transmission of Theileria hirci in sheep by hyalommaAnatolicum anatolicum. Tropical Animal Health and Production. 1973;5 2:103-9.

\section{Tables}

Table 1: Primers and target genes of pathogens investigated. 


\begin{tabular}{|c|c|c|c|c|c|}
\hline & Target gene & Primer Name & Primers $\left(5^{\prime}-3^{\prime}\right)$ & Annealing temperature $\left({ }^{\circ} \mathrm{C}\right)$ & Reference \\
\hline & \multirow{4}{*}{ 18S rRNA } & piro18S-F1 & GCGAATGGCTCATTAIAACA & \multirow[t]{4}{*}{58} & \multirow[t]{4}{*}{ Dahmana et al. 2019} \\
\hline & & piro18S-F4 & CACATCTAAGGAAGGCAGCA & & \\
\hline & & piro18S-F3 & GTAGGGTATTGGCCTACCG ${ }^{\mathrm{a}}$ & & \\
\hline & & piro18S-R3 & AGGACTACGACGGTATCTGA ${ }^{\mathrm{a}}$ & & \\
\hline \multirow{2}{*}{ eae } & \multirow{2}{*}{ 23S rRNA } & Ana23S-212f & ATAAGCTGCGGGGAGTTGTC & \multirow[t]{2}{*}{55} & \multirow[t]{2}{*}{ Dahmani et al. 2017} \\
\hline & & Ana23S-753r & TGCAAAAGGTACGCTGTCAC & & \\
\hline
\end{tabular}

Table 2: Prevalence of infection among cattle with tick-borne pathogens according to regions of Saudi Arabia.

\begin{tabular}{|c|c|c|c|c|c|c|c|c|c|c|c|c|c|}
\hline \multirow[t]{2}{*}{ Region } & \multirow[t]{2}{*}{$\begin{array}{c}\text { Examined } \\
\text { animals }\end{array}$} & \multicolumn{2}{|c|}{$\begin{array}{l}\text { Theileria } \\
\text { annulata }\end{array}$} & \multicolumn{2}{|c|}{ Theileria ovis } & \multicolumn{2}{|c|}{ Anaplasma ovis } & \multicolumn{2}{|c|}{ Co- infection } & \multicolumn{2}{|c|}{$\begin{array}{c}\text { Overall } \\
\text { prevalence }\end{array}$} & \multirow[t]{2}{*}{$\mathrm{x}^{2}$} & \multirow[t]{2}{*}{ Sig } \\
\hline & & Positive & $\%$ & Positive & $\%$ & Positive & $\%$ & Positive & $\%$ & Positive & $\%$ & & \\
\hline Riyadh & 173 & 6 & 3. 5 & 1 & 0.6 & 16 & 9.25 & 2 & 1.16 & 23 & 13.3 & 12.080 & 0.002 \\
\hline Al-Kharj & 101 & 0 & 0.00 & 0 & 0.00 & 0 & 0.00 & 0 & 0.00 & 0 & 0.00 & - & - \\
\hline Al-Hasa & 55 & 1 & 1.8 & 1 & 1.8 & 4 & 7.27 & 2 & 3.64 & 6 & 10 & 1.000 & ns \\
\hline $\begin{array}{l}\text { Al- } \\
\text { Qassim }\end{array}$ & 33 & 0 & 0.00 & 0.00 & 0.00 & 1 & 3.03 & 0 & 0.00 & 1 & 3.03 & - & - \\
\hline Total & 362 & 7 & 1.93 & 2 & 0.55 & 21 & 5.80 & 4 & 1.10 & 30 & 8.3 & 13.471 & 0.001 \\
\hline
\end{tabular}

ns= not significant

: Risk factors associated with Piroplasma and Anaplasma infections detected by PCR in cattle at different provinces of Saudi Arabia. 


\begin{tabular}{|c|c|c|c|c|c|c|c|c|}
\hline \multicolumn{2}{|c|}{ Factor } & \multirow{3}{*}{$\begin{array}{c}\text { Total animals } \\
225\end{array}$} & \multicolumn{2}{|c|}{ Bebesia } & \multicolumn{2}{|c|}{ Anaplasma } & \multirow{3}{*}{$\begin{array}{c}\mathrm{x}^{2} \\
6.545\end{array}$} & \multirow{3}{*}{$\begin{array}{l}\text { Sig. } \\
0.011\end{array}$} \\
\hline & & & \multirow{2}{*}{$\frac{\text { Positive }}{5}$} & \multirow{2}{*}{$\frac{\%}{2.22}$} & \multirow{2}{*}{$\frac{\text { Positive }}{17}$} & \multirow{2}{*}{$\begin{array}{c}\% \\
7.56\end{array}$} & & \\
\hline \multirow{4}{*}{ (year) } & $\leq 1$ & & & & & & & \\
\hline & $>1$ & 137 & 4 & 2.92 & 4 & 2.92 & 0.000 & ns \\
\hline & $x^{2}$ & & \multicolumn{2}{|c|}{0.111} & \multicolumn{2}{|c|}{8.049} & & \\
\hline & Sig. & & \multicolumn{2}{|c|}{ ns } & \multicolumn{2}{|c|}{0.005} & & \\
\hline \multirow{4}{*}{ der } & Male & 201 & 7 & 3.48 & 16 & 7.96 & 3.522 & ns \\
\hline & Female & 161 & 2 & 1.24 & 5 & 3.11 & 1.286 & ns \\
\hline & $x^{2}$ & & \multicolumn{2}{|c|}{2.778} & \multicolumn{2}{|c|}{5.762} & & \\
\hline & Sig & & \multicolumn{2}{|c|}{ ns } & \multicolumn{2}{|c|}{0.016} & & \\
\hline \multirow{4}{*}{$\mathbf{s}$} & Yes & 245 & 8 & 3.27 & 19 & 7.76 & 4.481 & 0.034 \\
\hline & No & 117 & 1 & 0.85 & 2 & 1.71 & 0.333 & ns \\
\hline & $x^{2}$ & & \multicolumn{2}{|c|}{5.444} & \multicolumn{2}{|c|}{13.762} & & \\
\hline & Sig. & & \multicolumn{2}{|c|}{0.020} & \multicolumn{2}{|c|}{$<0.001$} & & \\
\hline
\end{tabular}

Sig= significant, $\mathrm{ns}=$ not significant

\section{Figures}

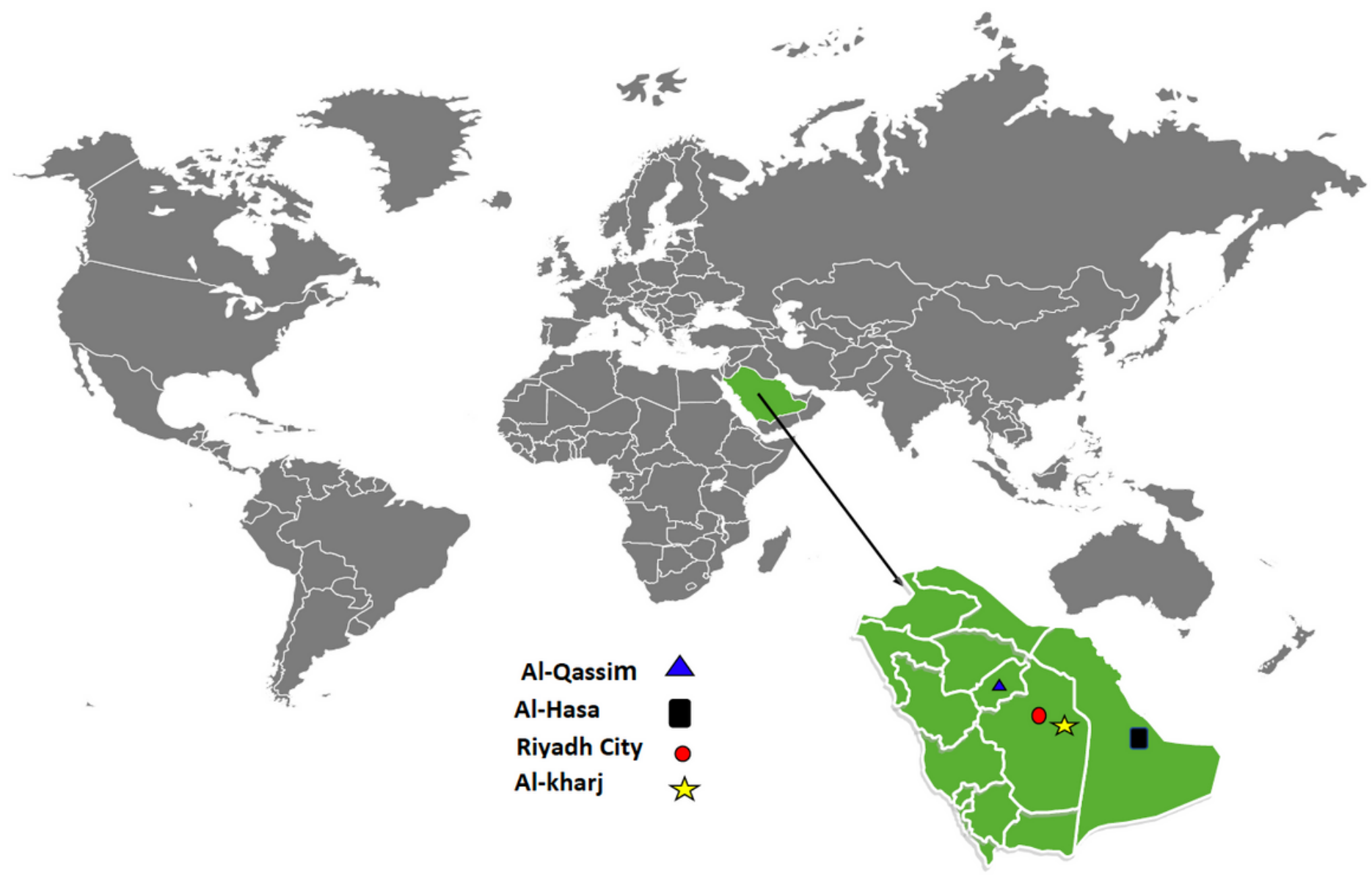

Figure 1 
Map showing the location of the study areas in Saudi Arabia. Note: The designations employed and the presentation of the material on this map do not imply the expression of any opinion whatsoever on the part of Research Square concerning the legal status of any country, territory, city or area or of its authorities, or concerning the delimitation of its frontiers or boundaries. This map has been provided by the authors.

\section{$\begin{array}{lllllllllllllll}M & P & N & 1 & 2 & 3 & 4 & 5 & 6 & 7 & 8 & 9 & 10 & 11 & 12\end{array}$}

\section{$1000 \mathrm{bp}$}

\section{Figure 2}

Image of agarose gel electrophoresis (1.5\%) showing $1100 \mathrm{pb}$ band for the amplification of $18 \mathrm{~S}$ rRNA gene of Piroplasma. Lane M: DL 2000 marker; Lane P: positive control; Lane N: negative control; lanes 111: negative samples; lane 12: positive sample.

\section{$\begin{array}{lllllllllllllll}M & 1 & 2 & P & N & 3 & 4 & 5 & 6 & 7 & 8 & 9 & 10 & 11 & 12\end{array}$}

\section{0 bp}

Figure 3 
Image of agarose gel electrophoresis (1.5\%) showing $520 \mathrm{pb}$ band for the amplification of 23S rRNA gene of Anaplasma. Lane M: DL 2000 marker; Lane P: positive control; Lane N: negative control; lanes 1-8, 11, 12: negative samples; lanes 9, 10: positive samples.

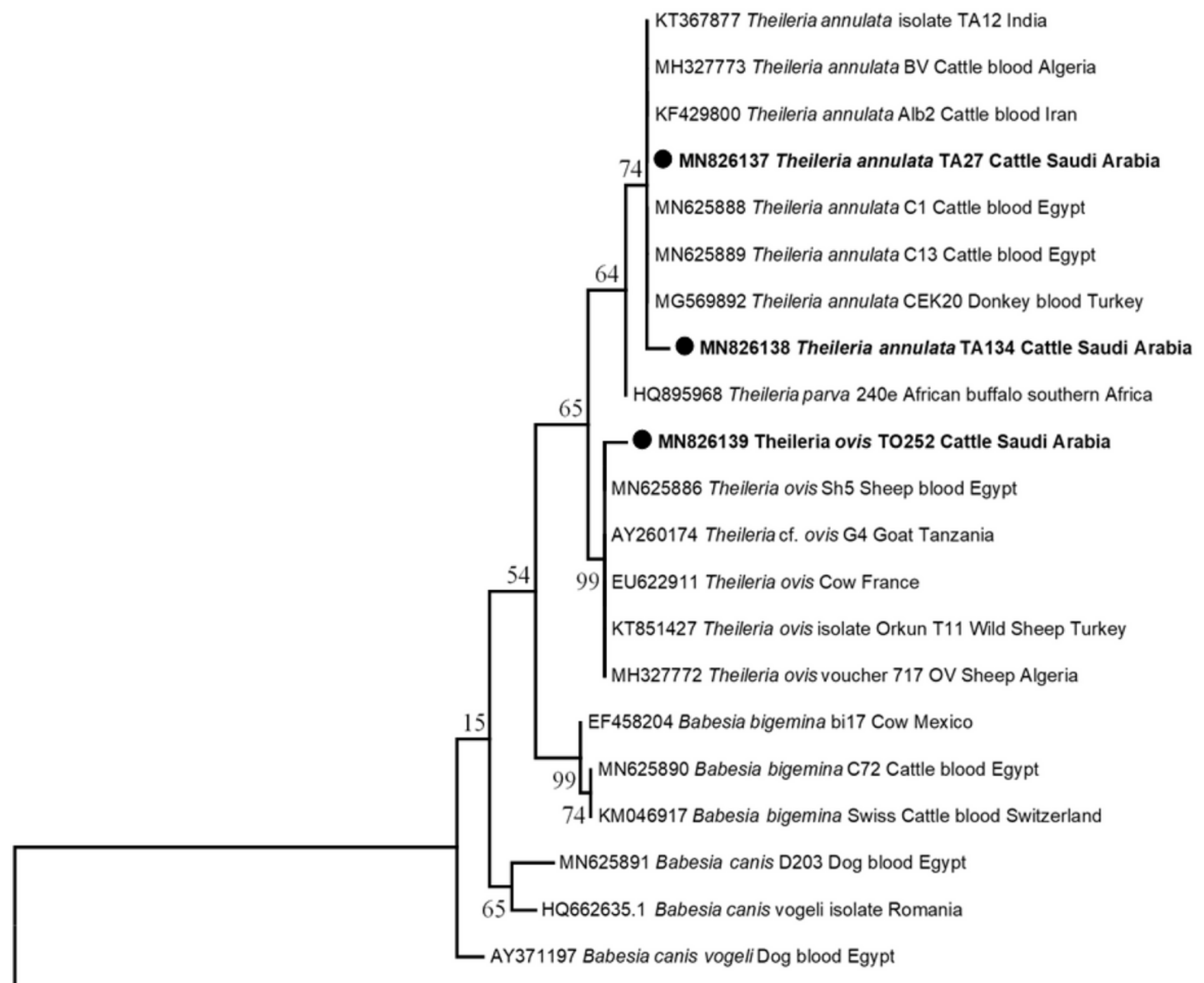

KT991233 Plasmodium falciparum Y21 China

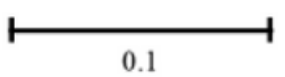

\section{Figure 4}

18S rRNA-based phylogenetic analysis of genotypes identified in this study. Phylogenetic tree highlighting the position of Theileria sp. in the present study (bold) related to other Theileria sp. available in GenBank. The sequences of 18S rRNA were aligned using CLUSTAL W and phylogenetic inferences were constructed in MEGA X using Maximum Likelihood based on Tamura-Nei Model for nucleotide sequences with 500 bootstrap replicates. There was a total of 491 positions in the final dataset. The scale bar represents a $5 \%$ nucleotide sequence divergence. 


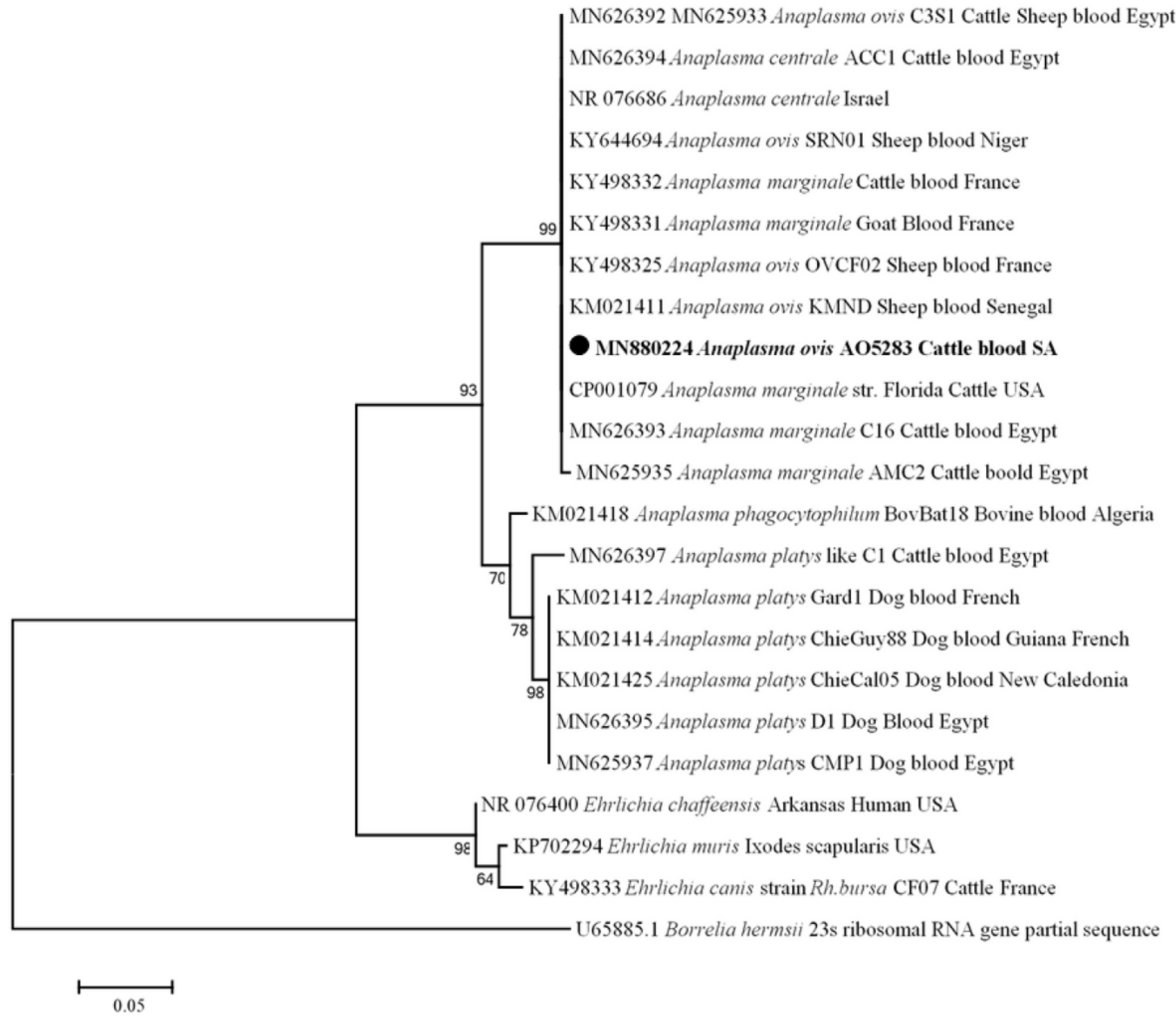

\section{Figure 5}

23S rRNA-based phylogenetic analysis of genotypes identified in this study. Phylogenetic tree highlighting the position of Anaplasma sp. in the present study (bold) related to other Anaplasma sp. available in GenBank. The sequences of 23S rRNA were aligned using CLUSTAL W and phylogenetic inferences were constructed in MEGA X using Maximum Likelihood based on Tamura-Nei Model for nucleotide sequences with 500 bootstrap replicates. There was a total of 435 positions in the final dataset. The scale bar represents a $5 \%$ nucleotide sequence divergence.

\section{Supplementary Files}


This is a list of supplementary files associated with this preprint. Click to download.

- GraphicalAbstract.pdf 